Article

\title{
Profile of the Spatial Distribution Patterns of the Human and Bacteriophage Virome in a Wastewater Treatment Plant Located in the South of Spain
}

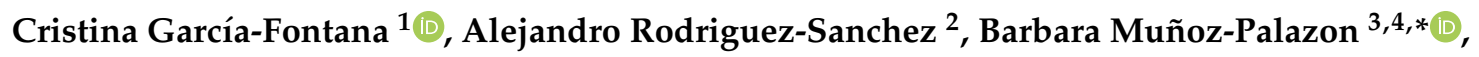 \\ Alejandro Gonzalez-Martinez ${ }^{3,4}$, Maria Vela-Cano ${ }^{3,4}$ and Jesus Gonzalez-Lopez ${ }^{3,4}$ \\ 1 Instituto de Investigación Biosanitaria de Granada (ibs.GRANADA), \\ Hospital Universitario San Cecilio de Granada, 18016 Granada, Spain; cgfontana@ugr.es \\ 2 Department of Horticulture and Landscape Architecture, Purdue University, 625 Agriculture Mall Drive, \\ West Lafayette, IN 47907, USA; rodri719@purdue.edu \\ 3 Institute of Water Research, University of Granada, C/Ramón y Cajal 4, 18071 Granada, Spain; \\ agon@ugr.es (A.G.-M.); mvc@ugr.es (M.V.-C.); jgl@ugr.es (J.G.-L.) \\ 4 Department of Microbiology, Faculty of Pharmacy, University of Granada, Campus of Fuentenueva s/n, \\ 18071 Granada, Spain \\ * Correspondence: bmp@ugr.es
}

Received: 26 June 2020; Accepted: 14 August 2020; Published: 18 August 2020

\begin{abstract}
In wastewater treatment plants, most microbial characterization has focused on bacterial, archaeal, and fungal populations. Due to the difficult isolation, quantification, and identification of viruses, only a limited number of virome studies associated with wastewater treatment plants have been carried out. However, the virus populations play an important role in the microbial dynamics in wastewater treatment systems and the biosafety of effluents. In this work, the viral members present in influent wastewater, mixed liquor (aerobic bioreactor), excess sludge, and effluent water of a conventional activated sludge system for the treatment of urban wastewater were identified. Viral members were observed by transmission electron microscopy and studied through next-generation sequencing studies. The results showed the dominance of bacteriophages in the viral community in all samples, with the dominant viral phylotype classified as Escherichia coli O157 typing phage 7. Moreover, different human viruses, such as Cynomolgus cytomegalovirus and Gammaherpesvirus, were also detected.
\end{abstract}

Keywords: next-generation sequencing; sewage virome; viral distribution; virus; transmission electron microscopy; wastewater treatment plant

\section{Introduction}

Viruses are the most abundant biological form in the world, and they play an important role in controlling the populations of the ecosystem through host-virus interrelations [1]. The most abundant human-associated viruses include rotaviruses, noroviruses, enteroviruses, astroviruses, and adenoviruses, which are widely found in urban wastewater worldwide [2,3]. Viruses are very difficult to quantify and detect. However, around 200 viral human pathogens have been identified [4]. The most common viral pathogens include adenovirus (AdV) group $\mathrm{F}$, hepatitis $\mathrm{A}$ and $\mathrm{E}$ viruses (HAV and HEV), norovirus genotype I and II (NoVGI and NoVGII), enterovirus A-D, and rotavirus A [5], but additional viruses and new diseases are continuously being discovered [6,7]. A few studies based on general viral contamination pointed out that adenoviruses serve as indicators [8-11]. It was estimated that 2 to 12 million people die every year from waterborne diseases [12]. Although this is sometimes caused by unidentified agents, research suggests that the main cause are enteric viruses 
located in groundwater or freshwater bodies [12,13]. However, until some years ago, microbial safety of water and wastewater has been determined exclusively by testing for bacterial indicators, mainly fecal coliforms and Escherichia coli, whose techniques fail as bioindicators to protect against parasitic protozoa, pathogenic viruses, or infectious fungi, which could survive for longer periods than bacteria. Viruses were described to persist for extended periods in water and are also more resistant to removal in comparison with bacteria [14-16].

Water supply concerns present a serious global threat that have been intensified with growing water demand. For this reason, marginal-quality water has become an essential component of agricultural water supplies, particularly in water-scarce countries, such as Spain, Italy, or Greece [17]. The reuse of treated wastewater is an essential and beneficial component for irrigation in agriculture; however, the presence of chemicals, bacteria, or viruses in this kind of water has been described as a potential risk for human health $[18,19]$. Despite the strict regulations, the irregular distribution of water resources causes serious deficit situations in important parts of the Mediterranean countries. For instance, agriculture is one of the most water demanding sectors in Spain (around $739.37 \mathrm{~m}^{3} / \mathrm{s}$ ). Thus, treated wastewater is a potential resource in this area, so the risks that the viruses pose in the effluent of wastewater treatment plants (WWTPs) must be controlled to avoid fecal contamination in agriculture production that could affect human and animal health.

The different steps within wastewater treatment plants lead to remove pathogen as well as an accumulation of microbial communities such as Bacteria, Archaea, Fungi, Protozoa, or Metazoa. Usually, activated sludge is the main process to remove pollutants. Still, its high concentration of microorganisms and nutrients promote the presence and abundance of viruses in this phase, which are 10 to 1000 times more abundant than in natural aquatic environments [9,10]. Additionally, viral particles are usually spread in the air, mainly situated above tanks, at a concentration of up to $10^{-4}$ most probable number (MPN) per liter [11]. However, the presence of the ultraviolet spectral range by solar radiation damages the structure of airborne viruses [20]. Virus populations in wastewater provide essential data about virus circulation, the development of novel viruses, and their transmission [21]. The discharge of both human pathogen and bacteriophages in treated wastewater to a natural environment impacts the receiving water bodies $[3,22]$. The conventional activated sludge (CAS) process spreads more pathogenic viruses in their discharges than other technologies. For instance, the removal efficiency of adenoviruses ranges from 1.3 to $2.4 \mathrm{log}$, while that in a membrane bioreactor (MBR) ranges from 3.4 to $5.6 \log$ [15]. Therefore, we described the regulatory role of bacteriophages in the prokaryotic community dynamics of biological wastewater treatment, considering that more than $96 \%$ of DNA viruses were bacterial phages [16].

The limited studies on environmental virome results in the lack of methods for monitoring and identifying this kind of biological entity spatially and seasonally. The novelty in metagenomics to identify viral particles is challenging from both experimental and computational aspects due to the nature of these particles. Viruses reside in a complex matrix within WWTPs. Analyzing this matrix is important to understanding the human health risks associated with the viral load in wastewater that is subsequently spread to natural resources and agriculture [23]. Additionally, it is essential to mention that the viral matrix in the different steps in a WWTP are related to the influent characterization, operational conditions, and implemented technology.

The main goals of this study were (1) to identify the viruses in different steps (influent wastewater, mixed liquor, sludge, and effluent water) of the full-scale WWTP from the city of Granada and a dairy factory; and (2) to check the distribution of the virome in the different stages of the wastewater treatment plant train.

\section{Materials and Methods}

\subsection{Wastewater Treatment Plant Characterization}

A municipal WWTP (Los Vados) located in Granada, Andalusia, Spain ( $\left.37^{\circ} 11^{\prime} 29.2^{\prime \prime} \mathrm{N} 3^{\circ} 40^{\prime} 35.0^{\prime \prime} \mathrm{W}\right)$, was evaluated in this study. This WWTP can treat $24,000 \mathrm{~m}^{3} /$ day using the CAS process, modified 
Ludzack-Ettinger (MLE), with sequential anoxic and aerated bioreactors. The Los Vados WWTP collects the influent from the west and north urban areas of Granada and also receives the discharge of a dairy factory, which consists of $20 \%$ of the total input to the CAS units. The WWTP consists of two primary settlers, followed by biological treatment of CAS equipped with facultative anoxic treatment, which is subsequently resolved with three secondary clarifiers [24]. In the aerated chamber, the dissolved oxygen was $3.6 \pm 0.4 \mathrm{mg} \cdot \mathrm{L}^{-1}$, while in the anoxic chamber, it was $0.7 \pm 0.1 \mathrm{mg} \cdot \mathrm{L}^{-1}$. Table 1 shows the operating conditions of the WWTP used for our study and some environmental parameters in which the activity was carried out.

Table 1. Main operational and environmental parameters of the Los Vados wastewater treatment plants (WWTP). Data were provided by the municipal wastewater company of Granada (Emasagra S.A.). HRT: hydraulic retention time; SRT: sludge retention time; TSS: total suspended solids.

\begin{tabular}{cc}
\hline Parameter & Value \\
\hline Bioreactor volume $\left(\mathrm{m}^{3}\right)$ & 3754 \\
Equivalent inhabitants & 223,000 \\
Flow rate $\left(\mathrm{m}^{3} / \mathrm{month}\right)$ & $552,295 \pm 9480$ \\
HRT $(\mathrm{h})$ & $4.9 \pm 0.1$ \\
SRT $($ day) & $4.0 \pm 0.2$ \\
TSS $(\mathrm{g} / \mathrm{L})$ & $5.05 \pm 0.57$ \\
\hline Maximum-minimum temperature $\left({ }^{\circ} \mathrm{C}\right)$ & $16.5 \pm 3.7$ to $2.8 \pm 3.4$ \\
Average temperature $\left({ }^{\circ} \mathrm{C}\right)$ & $9.3 \pm 2.9$ \\
Relative humidity $(\%)$ & $74.8 \pm 10.0$ \\
Wind speed $(\mathrm{m} / \mathrm{s})$ & $1.1 \pm 0.6$ \\
Average daily solar radiation $\left(\mathrm{Mj} / \mathrm{m}^{2}\right)$ & $12.5 \pm 6.6$ \\
Precipitation $(\mathrm{mm} /$ day) & $1.0 \pm 3.4$ \\
\hline
\end{tabular}

The physicochemical characteristics of the influent wastewater and effluent (treated water) in Los Vados WWTP were quite constant during the study period (Table 2). These data demonstrated high stability and good functioning of the WWTP. The analyses were done daily during the study period (January to April).

Table 2. Physicochemical characteristics of the influent wastewater (Inf) and effluent water (Eff) in the Los Vados WWTP. Data were provided by the municipal wastewater company of Granada (Emasagra S.A.).

\begin{tabular}{cccccc}
\hline & COD & BOD $_{5}$ & TN & TP & pH \\
\hline Influent & $653.8 \pm 27.7 \mathrm{mg} \mathrm{O}_{2} / \mathrm{L}$ & $374.4 \pm 23.5 \mathrm{mg} \mathrm{O}_{2} / \mathrm{L}$ & $97.4 \pm 0.2 \mathrm{mg} / \mathrm{L}$ & $11.5 \pm 2.3 \mathrm{mg} / \mathrm{L}$ & $7.7 \pm 2$ \\
Effluent & $70.0 \pm 2.4 \mathrm{mg} \mathrm{O}_{2} / \mathrm{L}$ & $12.2 \pm 1.3 \mathrm{mg} \mathrm{O}_{2} / \mathrm{L}$ & $52.3 \pm 8.3 \mathrm{mg} / \mathrm{L}$ & $1.0 \pm 0.2 \mathrm{mg} / \mathrm{L}$ & $7.7 \pm 2$ \\
Removal & $92.0 \pm 0.6 \%$ & $97.4 \pm 0.2 \%$ & $43.4 \pm 9.9 \mathrm{mg} / \mathrm{L}$ & $90.8 \pm 2.6 \mathrm{mg} / \mathrm{L}$ & \\
\hline
\end{tabular}

\subsection{Sample Collection and Nucleic Acid Extraction}

Samples were individually taken monthly for four months (January to April 2018) in sterile containers (2 L) from different points of the Los Vados WWTP, located in Granada, and they were kept at $4{ }^{\circ} \mathrm{C}$ and processed within the next $24 \mathrm{~h}$. The samples were collected from influent raw wastewater (IW), mixed liquor in the aerobic bioreactor (ML), excess sludge (EX), and effluent treated water (EW), which were transferred quickly to the laboratory, centrifuged in a Beckman Avanti centrifuge at $6000 \mathrm{rpm}$ for $1 \mathrm{~h}$, and then stored at $4{ }^{\circ} \mathrm{C}$. Subsequently, samples were filtered through a $0.45 \mu \mathrm{m}$ filter and mixed with 8\% PEG 8000 (Promega, Madison, WI, USA) and $0.3 \mathrm{M} \mathrm{NaCl}$ (pH adjusted to 7.2) following the protocol described by Aw et al. [25]. The samples were incubated at $4{ }^{\circ} \mathrm{C}$ for approximately $18 \mathrm{~h}$ and centrifuged in a Thermo Scientific SL 16R centrifuge at $7000 \mathrm{rpm}$ for $1 \mathrm{~h}$. The supernatant was discarded, and the pellet was suspended in $20 \mathrm{~mL}$ of phosphate-buffered saline (PBS) solution. Then, the concentrated biomass was filtered through a $0.22 \mu \mathrm{m}$ filter (CA-membrane sterile, Millipore, Billerica, MA, USA) to remove any remaining bacterial, archaeal, and eukaryotic cells. Both filters used were made of polycarbonate and sterile, and filters were not cation coated. Viral particles were concentrated using Amicon Ultra of $100 \mathrm{kDa}$ centrifugation columns (Millipore) 
at a total volume of $2 \mathrm{~mL}$. The remaining samples were subjected to a treatment for removing DNA not encapsulated in viral particles using DNAse treatment (Invitrogen, Catalogue Number AM1906, Carlsbad, CA, USA) [26].

The viral DNA was extracted from samples using a QIAmp MinElute Virus Spin Kit (Qiagen, Hilden, Germany) [25]. Viral RNA extraction was done with Trizol reagent (ThermoFisher Scientific, Waltham, MA, USA) [27], and reverse transcription to obtain cDNA was carried out using a SuperScript III First-Strand Synthesis System (Invitrogen) [28].

Finally, the pools of DNA and cDNA were mixed in equimolar concentrations, the quality of samples was measured by the Abs260/Abs280 ratio, and the pool was stored at $-20{ }^{\circ} \mathrm{C}$. Samples were sent to the Research and Testing Laboratory, Lubbock, Texas, for next-generation sequencing. First, samples were quality control checked using a Qubit 4.0 fluorometer and trace analyzed using a fragment analyzer. Once samples passed the quality control check, library preparation was started. Then, samples were fragmented using a Diagenode Biorupter. After samples were sonicated and were subjected to the KAPA HyperPrep DNA Library Kit library protocol. After library preparation, samples were quality checked using the Qubit 4.0 and fragment analyzer. Finally, samples were pooled and sequenced using an Illumina HiSeq instrument $(2 \times 300$ paired-end reads). The concentrations of DNA, RNA, cDNA, and DNA + cDNA of all samples were measured using $1 \mu \mathrm{L}$ of each pool carried out by spectrophotometric method using a Thermo Scientific ${ }^{\mathrm{TM}}$ NanoDrop 2000 during each stage of nucleic acid extraction.

\subsection{Visualization of Viral Particles by TEM}

Concentrated virus particles were visualized using transmission electron microscopy (TEM) in the Scientific Instrumentation Center (CIC) of the University of Granada. Firstly, $30 \mathrm{~mL}$ of viral suspension was recovered using a carbon film for $5 \mathrm{~min}$. The sample was washed with ultrapure water, and subsequently, a negative stain with 1\% uranyl acetate was performed [29]. The sample was visualized with a Zeiss EM Libra 120 Plus TEM at an accelerating voltage of $120 \mathrm{kV}$ using a lanthanum hexaboride thermionic filament.

\subsection{Bioinformatics Pipeline}

All sequences were processed using mothur [30] and BLAST [31] software. First, paired-end sequences were assembled into contigs using mothur through an alignment under Needleman conditions that allowed the generation of ambiguous base pairs when the Phred quality score was six or lower. After making contigs, these were screened to remove those with more than 0 ambiguous bases and homopolymers longer than eight base pairs. After this screening, a pipeline similar to that used by Zhao et al. [32] was followed. In the first step, the contigs were blasted using blastn against the nucleotide database VirusDBNT_20160802_ID98. The contigs with an e-value $<10^{-5}$ were considered positive matches and classified as viral. The remaining contigs were then blasted using blastx against the protein database VirusDBNR_20160802_ID98. Those matches with an e-value $<10^{-3}$ were considered viral. Remaining contigs were then mapped against the collection of reference prokaryotic representative genomes derived from the NCBI (10/17/2018) using BLAST and blastn, and those that had a match with an alignment score $>50$ were considered bacterial DNA and removed from the analysis. Meanwhile, those with an alignment score $<50$ were considered viral sequences. These viral sequences were classified through BLAST software in successive steps. First, viral sequences were blasted through MEGAblastn against the NCBI nt database (17 November 2018), considering those with an e-value $<10^{-10}$ as positive matches. Non-positive matches were then blasted through blastn against the NCBI nt database (17 November 2018), considering those with an e-value $<10^{-10}$ as positive matches. Non-positive matches were then blasted through blastx against the NCBI nr database (20 November 2018), considering those with an e-value $<10^{-3}$ as positive matches. The viral sequences that had no positive matches were considered as non-identified. All identified sequences (those with a positive match in any of the BLASTs) were then taxonomically classified using the C-RVDB v15.1 [33]. 
The raw data from Illumina have been uploaded to the NCBI database under the accession PRJNA641872.

\section{5. $\alpha$-Diversity Indices and Similarity Analyses of Samples}

Analysis of species richness, diversity, and evenness of each sample were calculated using the Chao-1 estimator, Shannon-Wiener, and Simpson diversity indices in the PASTv3 software. Similarities of viral communities among the different samples were observed by means of principal components analysis (PCA) and singular value decomposition (SVD). For the PCA, the counts table was used to compute it based on Bray-Curtis distances and the vegan package implemented in R software. SVD was calculated using the robCompositions package [34] implemented in $\mathrm{R}$, and for this, we used a centered log-ratio transformed viral counts table. The centered log-ratio transformation of the viral counts table was done using the zCompositions package [34] implemented in R, for which zero values were replaced using a count-zero multiplicative method by Bayesian multiplicative replacement.

\subsection{Differential Abundance of Viral Phylotypes}

The differential representation of viral phylotypes among the different samples was assessed by means of expected effect size (EES), differential expression analysis (DEA), and similarity percentage (SIMPER) analyses.

SIMPER analysis was done using the viral counts table calculated for partition one (P1), the influent sample, and partition two (P2), the effluent water, sludge excess, and biological reactor, through PASTv3 software, and computed based on Bray-Curtis distances with 9999 bootstrap replications. For the computation of EES, the package ALDEx2 [34] was used, first for correction to avoid zero counts in the viral counts table, and then for the transformation to a centered log-ratio using 128 Dirichlet Monte-Carlo distributions. The DEA was calculated using the package edgeR [35] implemented in R, using a confidence of 0.05 and 10,000 bootstrap replications

\subsection{Multivariate Redundancy Analysis}

A multivariate redundancy analysis was done to observe the linkage between dominant viral phylotypes with operational parameters (COD, BOD, TN, TP) and the relationships of viral phylotypes with the selected points within a biological treatment. The computation was done by 499 unconstrained Monte-Carlo simulations under a full model in CANOCO 4.5 for Windows [36].

\section{Results and Discussion}

\subsection{Quality of the Viral Nucleic Acid Extraction Protocol}

First, and before starting with the viral phylogenetic analysis, it was necessary to check whether the protocol used in the extraction of the viral nucleic acid using the Nanodrop as a molecular method was useful for the studying the virome in the WWTP. Table 3 shows the quality and efficiency of the extraction protocol used in our study. In this sense, our data showed high quality in the standard values of all nucleic acid samples extracted during the study based on the high Abs260/Abs280 values (1.8 to 2.0$)$. We can confirm that the Nanodrop allows us to adequately analyze the virome quality and concentration of a WWTP analogously to other studies that were previously done [37].

Table 3. Concentration (ng/ $\mu \mathrm{L})$ of DNA, RNA, cDNA, DNA + cDNA, and Abs260/Abs280 ratio in the extracted viral nucleic acid samples.

\begin{tabular}{cccccc}
\hline Sample & DNA & RNA & cDNA & DNA + cDNA & Abs260/Abs280 \\
\hline Influent water (IW) & 61 & 40 & 1310 & 71 & 1.98 \\
Mixed liquor (MX) & 56 & 50 & 1612 & 61 & 1.91 \\
Excess sludge (ES) & 57 & 70 & 1413 & 65 & 1.84 \\
Effluent water (EW) & 108 & 52 & 1372 & 112 & 1.96 \\
\hline
\end{tabular}




\subsection{Viral Particle Morphology by TEM}

TEM observations showed viral morphologies that corresponded to viruses which infect eukaryotic cells and bacteriophages. However, TEM analysis showed some differences depending on the sampling place. Thus, in the influent samples (Figure 1A), a wide diversity of Eukarya viral particles and bacteriophages were detected with a highly conserved morphology. An analogous situation was observed in the samples obtained from the WWTP effluent and sludge (Figure 1C,D), where the presence of eukaryotic viral particles and bacteriophages was also detected. However, when aerobic bioreactor samples (mixed liquor) were observed by TEM, practically only virions with bacteriophage morphology were detected since bacteria could multiply and function as hosts for their viruses (Figure 1B). Although these results are simply a qualitative observation, they might suggest that the virome in the biological reactor was dominated by bacterial viruses, something that is logical if we consider the high amount of active bacterial biomass present in this habitat [38].

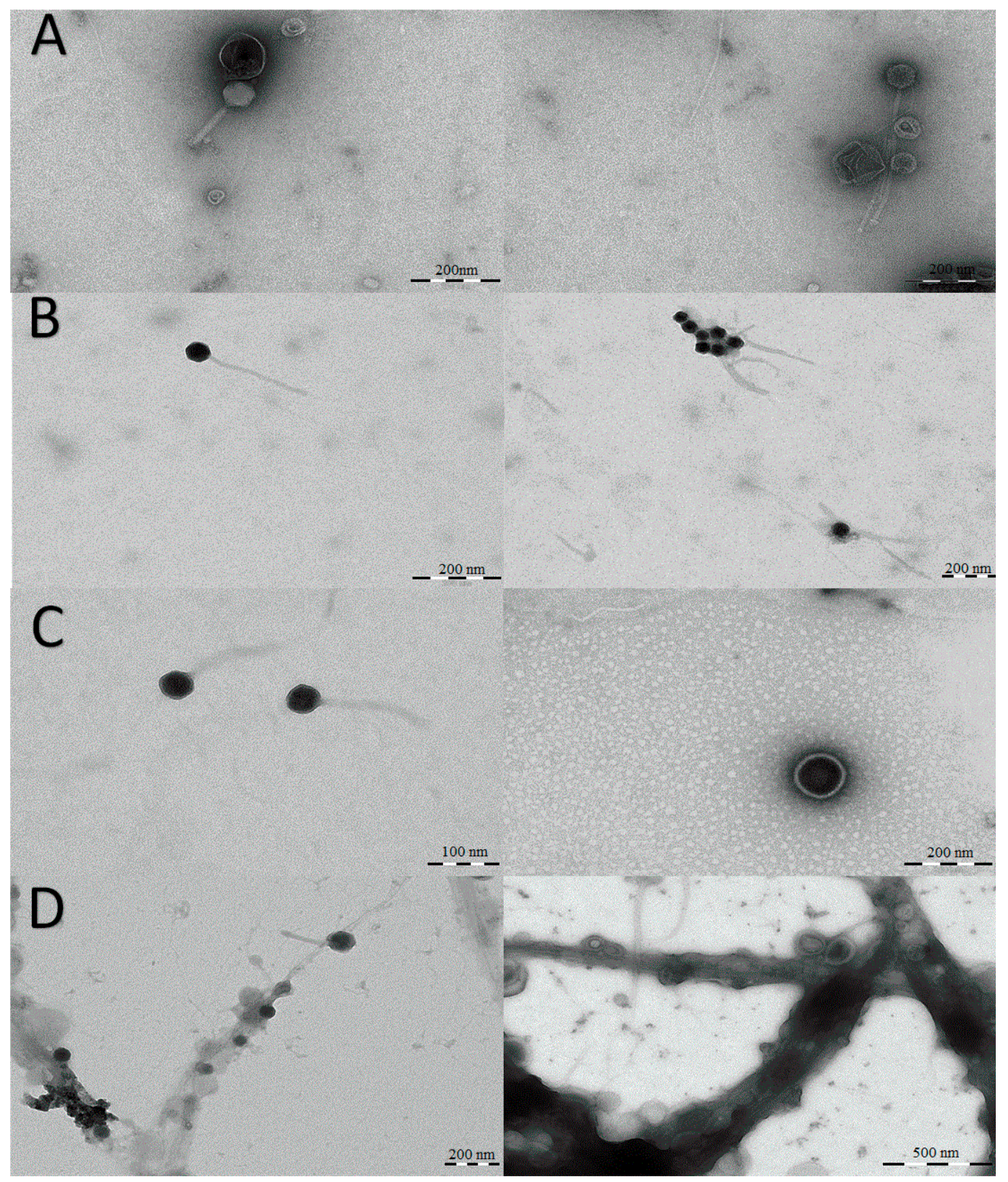

Figure 1. The most representative viral morphologies observed in influent urban wastewater (Line A), mixed liquor (Line B), effluent treated water (Line C), and sludge excess (Line D) of the Los Vados WWTP. 
The TEM studies also suggested that the samples examined from the WWTP effluents contained a lower number of viral particles in relation to the other samples examined. These preliminary results were subsequently corroborated by massive parallel sequencing studies. Other authors have previously described similar results [39], which indicated that a decrease in the number of viral particles occurs as a consequence of wastewater treatment.

\subsection{Viral Phylotypes in the Wastewater Treatment Plant}

Zhang et al. [40] described the significant role of bacteriophages in the optimum operation of WWTPs and their importance in the improvement of effluent quality. In this study, the dominant viral phylotypes found in wastewater samples were mostly related to bacteriophages regardless of the sampling point (Figure 2). Specifically, the dominant viral phylotype in the WWTP was classified as Escherichia coli $\mathrm{O} 157$ typing phage 7. This result was not surprising since E. coli phages are one of the most common viruses in WWTP [41], and coliphages have been widely employed as indicators and source tracking markers of fecal pollution of water [42]. Particularly, E. coli O157 phage 7 has been used as a biocontrol agent in several food industries, due to the frequent contamination of foods with E. coli O157:H7 [43]. Actually, the great diversity of E. coli phage had been reported widely [41,42]. Specifically, the phage E. coli had been associated with cattle, where the bacteria may be spread among the animals asymptomatically, suggesting the deep and strong effect that the dairy influent in Los Vados WWTP could have in the virome community [44-46].

Seasonal changes in E. coli O157 phage 7 populations, their intermittent presence in WWTPs, and their decrease during urban wastewater treatment processes have been described [39]. However, in this study, we observed that this bacteriophage accounts for more than $10 \%$ of the total viral community, independently of the samples examined (influent wastewater, mixed liquor, sludge, and effluent water), suggesting that this phylotype could be considered a predominant member in the virome of the WWTP.

The Pseudomonas phage LKA 1 and Aeromonas phage vB also observed in high abundance, although these phylotypes were mainly detected in influent wastewater samples. Pseudomonas and P. aeruginosa bacteriophages have been widely studied in WWTPs due to the infectious character of these bacteria in humans $[40,47,48]$. Pseudomonas phages are known to affect key aspects of Pseudomonas such as biofilm formation, virulence, and antibiotic resistance [49]. In this sense, Pseudomonas phages have been proposed to remove fixed biofilms produced by Pseudomonas in WWTPs [47]. It was reported that a $1 \mathrm{~h}$ dose of phages at the concentration of $5.1 \times 10^{6} \mathrm{PFU} / \mathrm{mL}$ and flow rate of $1.6 \mathrm{~mL} / \mathrm{min}$ was able to remove $P$. aeruginosa from different biofilter systems with ratios ranging from $56 \%$ to $70 \%$. Therefore, the small doses of phages led to a decrease in the presence of $P$. aeruginosa in the effluent and also promoted and controlled the ammonia-oxidizing bacteria in biofilter technologies $[40,48]$. Finally, it should be noted that Pseudomonas phages have been investigated as a potential therapeutic tool when infections caused by this bacterium are highly resistant to antibiotics [50].

This study showed the presence of $P$. aeruginosa phages in the influent water, while both sludge and effluent samples showed no presence or very low relative abundance of these bacteriophages. This suggests that $P$. aeruginosa phages are practically removed during the different steps that occur in WWTPs [41]. A similar behavior was observed for Aeromonas phages, which were abundantly identified in the influent water but were practically absent in the aerobic bioreactor (mixed liquor), effluent, and sludge samples.

Edwardsiella phages were found in mixed liquor samples obtained from the aerobic bioreactor at a relative abundance $>1 \%$, but which are commonly reported in activated sludge systems [51]. Two Escherichia bacteriophages were found in sludge samples. Finally, in the effluent water, a high representation of one Enterobacteria phage was detected together with E. coli phages. 


\begin{tabular}{|c|c|c|c|c|c|c|c|c|}
\hline OTU & Taxonomy & IW & EW & ES & ML & C.D. & & \\
\hline Otu0007 & Edwardsiella phage MSW-3 DNA, complete genome & & & & & & Color Code & Color Code \\
\hline Otu0061 & Pseudomonas phage H66 & & & & & & $\mid 0.00 \%$ & \begin{tabular}{l|l|} 
& $0.00 \%$ \\
\end{tabular} \\
\hline Otu0092 & Pseudomonas phage LKA1 complete genome, specific host Pseudomonas aeruginosa & & & & & & $0.25 \%$ & $1.00 \%$ \\
\hline Otu0106 & Burkholderia cepacia phage Bcep22, complete genome & & & & & & $0.50 \%$ & $2.00 \%$ \\
\hline Otu0110 & Bordetella phage BIP-1, complete genome & & & & & & $0.75 \%$ & $3.00 \%$ \\
\hline Otu0222 & Enterobacteria phage phiX174 isolate JACSK, complete genome & & & & & & $1.00 \%$ & $4.00 \%$ \\
\hline Otu0227 & Rhodococcus phage ReqiPoco6, complete genome & & & & & & $\mathbf{2 . 5 0} \%$ & $5.00 \%$ \\
\hline Otu0268 & Pseudomonas phage phi297, complete genome & & & & & & $5.00 \%$ & $6.00 \%$ \\
\hline Otu0322 & Pseudomonas phage $\mathrm{PaMx74, \text {partialgenome }}$ & & & & & & $7.50 \%$ & $7.00 \%$ \\
\hline Otu0326 & Aeromonas phage vB_AsaM-56, complete genome & & & & & & $\geq 10.00 \%$ & $8.00 \%$ \\
\hline Otu0396 & Pseudomonas phage H66, complete genome & & & & & & & $9.00 \%$ \\
\hline Otu0420 & Escherichia phage 1720a-02, complete genome & & & & & & & $\geq 10.00 \%$ \\
\hline Otu0500 & Escherichia coli 0157 typing phage 7, partial genome & & & & & & & \\
\hline Otu0511 & UNVERIFIED: Cynomolgus cytomegalovirus isolate 31909 & & & & & & & \\
\hline Otu0517 & Human gammaherpesvirus 4 isolate ebv14 & & & & & & & \\
\hline Otu0521 & Pseudomonas phage D3 & & & & & & & \\
\hline Otu0779 & Rhodococcus phage ReqiPepy6 & & & & & & & \\
\hline
\end{tabular}

Figure 2. Dominant bacteriophage phylotypes found in different sampling place in a full-scale WWTP. IW: influent wastewater; EW: effluent water; ES: excess sludge; and ML: mixed liquor from the aerobic bioreactor, C.D.: contribution to dissimilarity as per SIMPER. 
The results of this study suggested that the stages of treatment produced changes in the diversity of the bacteriophage community in the inlet water (influent), mixed liquor, excess sludge, and treated water (effluent) of activated sludge at a full-scale urban WWTP. However, some phylotypes such as Escherichia coli $\mathrm{O} 157$ typing phage 7 were present in all of the treatment steps tested (water line and sludge line). These results demonstrate that some bacteriophages in a WWTP could be a constant part of the viral community and represent a stable fraction of a biological complex matrix that characterizes the virome of the WWTP. This fact could be relevant in biological wastewater technologies due to the important role that bacteriophages play in aspects such as the stability of bacterial communities, the removal of pathogens, and the limitation exerted on the bacteriophage community regarding horizontal gene transfer in the complex matrix of activated sludge [38,52,53].

Human viruses were also detected in the WWTP, and this is consistent with other reports [41]. Thus, the most abundant phylotype detected in the influent water, mixed liquor, sludge, and effluent was affiliated with Cynomolgus cytomegalovirus isolate 31909 (Figure 3), which has been reported as a widespread opportunistic pathogen affecting immunocompromised individuals and was previously found in urban wastewater [54]. Gammaherpesvirus 4 isolate ebv14 was also found in all of the sampling locations in the WWTP, although it was always detected in effluent water at a very low relative abundance (Figure 3). Gammaherpesviridae are a subfamily of DNA viruses of vertebrates of the Herpesviridae family, which are lymphoproliferative viruses that can become latent in B.1 lymphocytes. According to our knowledge, this is the first time that the presence of this type of virus has been reported in effluent water from a WWTP, although it has been previously reported in WWTP systems by Simmons et al. [15].

Hepatitis $\mathrm{C}$ virus (HCV)-related sequences were found in high abundance in the influent wastewater (Figure 3). However, this phylotype was not detected in the mixed liquor, sludge, and effluent samples. This result could suggest that the presence of this phylotype in the urban wastewater was probably due to human or animal fecal contamination. These data may be surprising, since there is no evidence that this virus has been described in wastewater. However, it has been previously described in aquatic environments affected by farm animals [55], and this could be the case in our research, given that we analyzed the dairy factory effluents treated in the WWTP. However, the hepatitis $C$ virus is present in high enough amounts in rectal mucus to allow transmission of this virus, according to a study conducted with men co-infected with HIV and HCV [56]. Consequently, its presence in urban wastewater must be considered as possible.

When the presence of viruses which infect eukaryotic cells in the excess sludge was studied, high diversity and abundance was detected with Prunus necrotic ringspot virus and Cytomegalovirus as the most dominant (Figure 3). However, it is noteworthy that a very low diversity of viruses which infect eukaryotic and human cells was observed in the effluent water. These data suggest that the wastewater treatment process efficiently removes the viral load from the waterline. However, an important fraction of the viral load was deposited in the sludge generated during the biological treatment process. 


\begin{tabular}{|c|l|}
\hline OTU & \\
\hline Otu0031 & Stealth virus 1 clone C16147 T3. \\
\hline Otu0043 & Homo sapiens clone BAC_22700 cytotoxic T-lymphocyte-associated protein 4 (CTLA4) and inducible T-cell co-stimulator (ICOS) genes \\
\hline Otu0044 & Homo sapiens clone BAC_22608 inducible T-cell co-stimulator (ICOS) gene \\
\hline Otu0080 & Hepatitis C virus S53/6 mRNA for Ig V region light chain. \\
\hline Otu0093 & Prunus necrotic ringspot virus mRNA for coat protein (CP gene) from Kullu \\
\hline Otu0102 & Pongo pygmaeus isolate 1 endogenous retrovirus ERV-W \\
\hline Otu0140 & Homo sapiens gypsy retrotransposon integrase 1 \\
\hline Otu0153 & Homo sapiens endogenous virus Human endogenous retrovirus K HERV-K52 \\
\hline Otu0154 & Homo sapiens endogenous virus Human endogenous retrovirus K HERV-K59 \\
\hline Otu0238 & Human papillomavirus type 16 proviral 3' integration site \\
\hline Otu0305 & Homo sapiens isolate HML-2_9q34.3 endogenous virus HERV-K \\
\hline Otu0494 & Uncultured virus clone DTF1061043184819_1_1504_1 ribonucleotide reductase gene \\
\hline Otu0503 & Uncultured marine virus isolate Anoxic2_1 genomic sequence. \\
\hline Otu0504 & Uncultured marine virus isolate H4084949 genomic sequence. \\
\hline Otu0506 & Gossypium raimondii isolate Gr87 retrotransposon Ty3 \\
\hline Otu0508 & HIV-1 isolate M0107v1d14-5M15-C1 from USA genomic sequence. \\
\hline Otu0511 & UNVERIFIED: Cynomolgus cytomegalovirus isolate 31909 \\
\hline Otu0515 & Paramecium bursaria Chlorella virus 133 kDa in vitro translation peptide gene \\
\hline Otu0516 & Siphoviridae sp. isolate ctcf5 \\
\hline Otu0517 & Human gammaherpesvirus 4 isolate ebv14
\end{tabular}

Total abundance
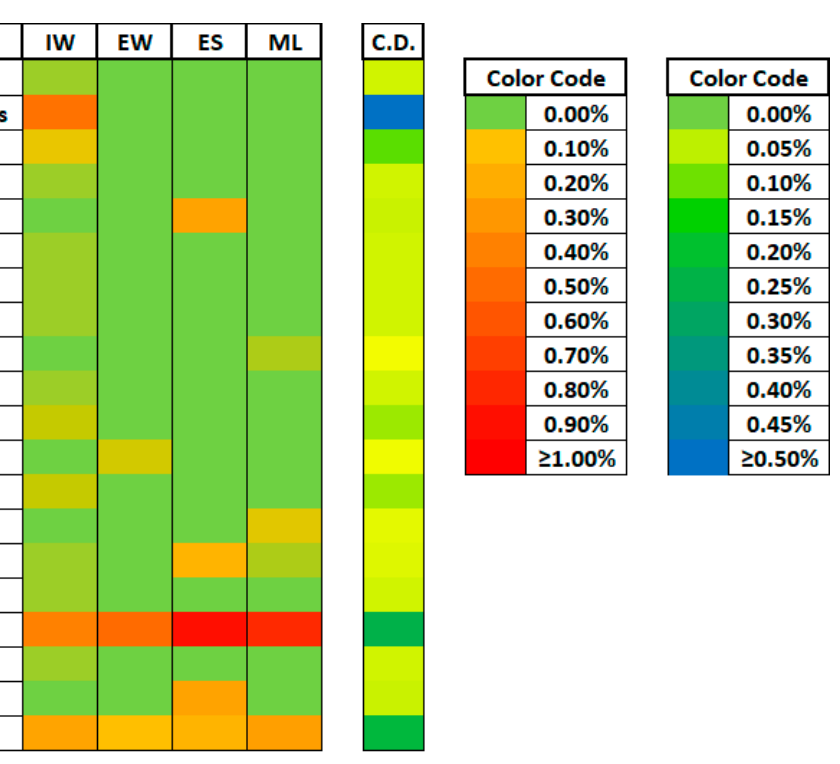

$|1.50 \%| 0.67 \%|1.71 \%| 1.19 \%$

Figure 3. Dominant viral phylotypes that infect eukaryotic cells found in different sampling locations in an at full-scale. IW: influent wastewater; EW: effluent water;

ES: excess sludge; and ML: mixed liquor from the aerobic bioreactor, C.D.: contribution to dissimilarity as per SIMPER. 


\subsection{Distribution of Viral Phylotypes in the Wastewater Treatment Plant}

The species richness calculated by the Chao-1 index showed that samples from influent wastewater have higher values, while those values in the effluent water and mixed liquor were much lower. Nonetheless, the lowest values of richness were detected in the samples obtained from excess sludge (Table 4).

The $\alpha$-diversity measured by Simpson and Shannon-Wiener indices showed that the highest diversity was found in influent samples. In contrast, the samples from excess sludge and mixed liquor were approximately similar to 1 . Finally, the effluent samples registered the lowest diversity. These data seem to confirm the hypothesis that effective wastewater treatments can reduce viral load and diversity, which is important to help minimizing the public health risks based on the exposure to effluent water containing viruses [55]. Additionally, the evenness and diversity measured by Simpson indices suggested that the lowest values detected in the influent samples could be due to E. coli phage H7, P. aeruginosa phage, and Aeromonas phage, which were the dominant phylotypes in the community.

Table 4. Species richness, diversity, and evenness indices in wastewater treatment plant.

\begin{tabular}{cccc}
\hline Samples & Chao-1 & Shannon-Wiener & Simpson \\
\hline Influent water (IW) & 1566.6 & 2.7 & 0.4 \\
Effluent water (EW) & 412.3 & 1.1 & 0.7 \\
Excess sludge (ES) & 333.8 & 1.2 & 0.6 \\
Mixed liquor (ML) & 441.4 & 1.2 & 0.7 \\
\hline
\end{tabular}

All statistical analyses used for the clustering of viral phylotypes suggested a clear differentiation between the viral communities in the influent wastewater samples and the other samples studied (mixed liquor, sludge, and effluent water). However, these clustering analyses also suggested an important similarity in viral communities in the mixed liquor, excess sludge, and the outlet water (effluent) of the WWTP (Figure 4). The results suggested that the WWTP process has a strong influence on the composition of the viral community structure in the activated sludge wastewater treatment system $[57,58]$.

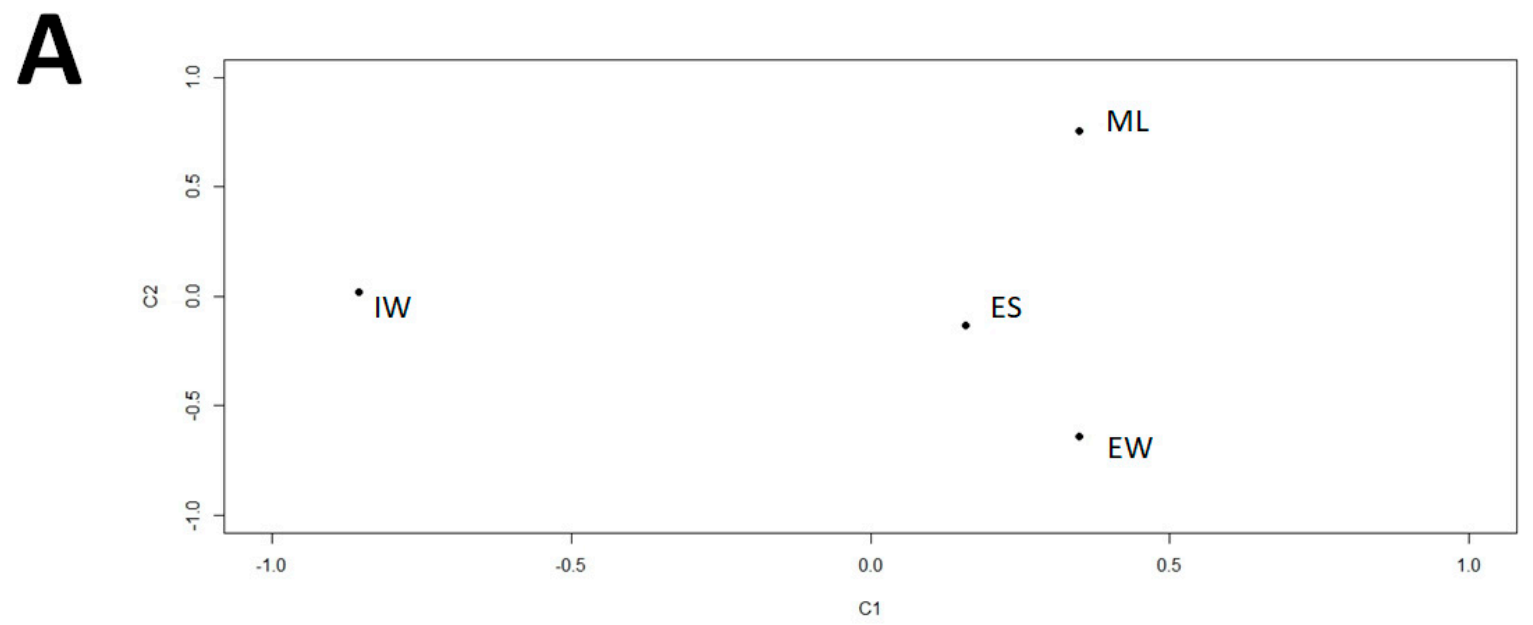

Figure 4. Cont. 
B

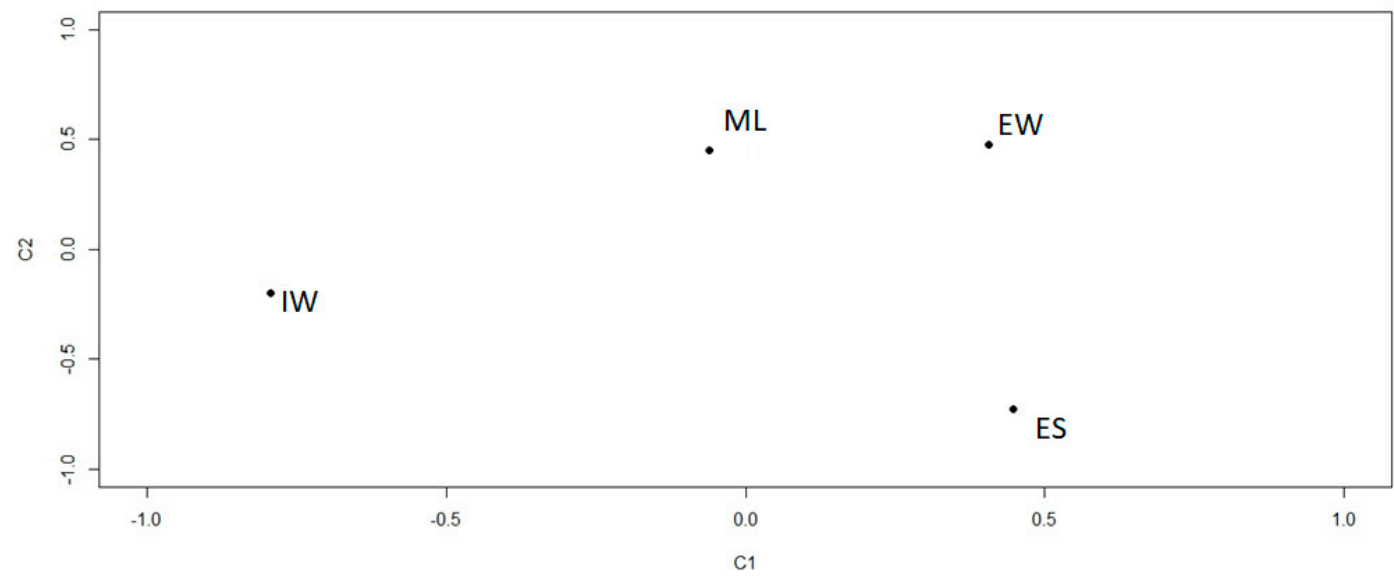

Figure 4. Cluster analysis of the total virome in the WWTP (A) and Eukarya-infecting viruses in the WWTP (B) calculated by singular value decomposition (SVD).

\subsection{Sensitive Viral Phylotypes}

SIMPER analysis showed that the viral phylotypes detected in the WWTP that contributed more to the dissimilarity between influent samples and the rest of sampling points (mixed liquor, sludge, and effluent) in the wastewater treatment process were mainly composed by E. coli O157 typing phage 7, Pseudomonas phage LKA1, and Aeromonas phage vB_AsaM-56 (Figure 5). Despite E. coli O157 phage 7 being the phylotype dominant with more than $10 \%$ of total relative abundance in all of the samples, the differences between groups of samples were mainly driven by P. aeruginosa phage and Aeromonas phage, which were absent in the aerobic reactor, excess sludge, and effluent water of the WWTP.

The control of bacterial populations by bacteriophages in WWTPs has been extensively studied $[38,40]$. In this sense, the bacteriophage community must be considered essential in the lysis of certain human pathogenic microorganisms, such as Enterobacteriaceae. For this reason, urban wastewater treatment processes must be considered important not only for nutrient removal $(\mathrm{C}, \mathrm{N}$, or $\mathrm{P})$, but also for the removal of bacterial and virus pathogens [46,57].

Statistical analysis with EES and DEA showed that the structure of the virome in the WWTP was only affected in its bacteriophage community in response to the sampling point (Figure 6). In contrast, the viral community which infects eukaryotic cells (specifically human) was similar in all the samples studied (influent water, mixed liquor, sludge, and effluent water). This seems to suggest that the urban wastewater treatment process modified the diversity of the bacterial virus community, but it did not seem to affect the diversity of the human viruses [41]. However, these results require complementary quantitative studies, since the methodology used in this study only permits establishing a relative abundance of phylotypes. 


\begin{tabular}{|c|c|c|c|c|}
\hline OTU & Taxonomy & P1 & $\mathbf{P 2}$ & C.D. \\
\hline Otu0007 & Edwardsiella phage MSW-3 DNA, complete genome & & & \\
\hline Otu0061 & Pseudomonas phage $\mathrm{H} 66$ & & & \\
\hline Otu0092 & Pseudomonas phage LKA1 complete genome, specific host Pseudomonas aeruginosa & & & \\
\hline Otu0106 & Burkholderia cepacia phage Bcep22, complete genome & & & \\
\hline Otu0110 & Bordetella phage BIP-1, complete genome & & & \\
\hline Otu0222 & Enterobacteria phage phiX174 isolate JACSK, complete genome & & & \\
\hline Otu0227 & Rhodococcus phage ReqiPoco6, complete genome & & & \\
\hline Otu0268 & Pseudomonas phage phi297, complete genome & & & \\
\hline Otu0322 & Pseudomonas phage PaMx74, partial genome & & & \\
\hline Otu0326 & Aeromonas phage vB_AsaM-56, complete genome & & & \\
\hline Otu0396 & Pseudomonas phage $\mathrm{H66}$, complete genome & & & \\
\hline Otu0420 & Escherichia phage 1720a-02, complete genome & & & \\
\hline Otu0500 & Escherichia coli 0157 typing phage 7, partial genome & & & \\
\hline Otu0511 & UNVERIFIED: Cynomolgus cytomegalovirus isolate 31909 & & & \\
\hline Otu0517 & Human gammaherpesvirus 4 isolate ebv14 & & & \\
\hline Otu0521 & Pseudomonas phage D3 & & & \\
\hline Otu0779 & Rhodococcus phage ReqiPepy6 & & & \\
\hline
\end{tabular}

\begin{tabular}{|} 
Color Code \\
\hline \begin{tabular}{|c|}
\hline $0.00 \%$ \\
\hline $1.00 \%$ \\
\hline $2.00 \%$ \\
\hline $3.00 \%$ \\
\hline $4.00 \%$ \\
\hline $5.00 \%$ \\
\hline $6.00 \%$ \\
\hline $7.00 \%$ \\
\hline $8.00 \%$ \\
\hline $9.00 \%$ \\
\hline$\geq 10.00 \%$ \\
\hline
\end{tabular}
\end{tabular}

Figure 5. SIMPER analysis of influent water partition (P1) and mixed liquor, sludge, and effluent water partition (P2) of the viral community. C.D.: contribution to dissimilarity as per SIMPER analysis. 


\begin{tabular}{|c|c|c|c|c|c|c|}
\hline OTU & Taxonomy & IW & EW & ES & ML & \\
\hline Otu0007 & Edwardsiella phage MSW-3 DNA & & & & & \\
\hline Otu0038 & Bacteriophage HK97 & & & & & \\
\hline Otu0043 & Enterobacteria phage P1 mod1902::IS5 c1.100 rev dmt(del)MB mutant & & & & & \\
\hline Otu0072 & Synechococcus phage S-CBS4 & & & & & Color Code \\
\hline Otu0089 & Escherichia coli 0157 typing phage 4 & & & & & $0.00 \%$ \\
\hline Otu0092 & Modification methylase BamHII & & & & & $0.10 \%$ \\
\hline Otu0099 & Pseudomonas phage PaMx25 & & & & & $0.20 \%$ \\
\hline Otu0147 & uncultured Mediterranean phage uvMED & & & & & $0.30 \%$ \\
\hline Otu0169 & Bacteriophage PA11 & & & & & $0.40 \%$ \\
\hline Otu0178 & Rhodococcus erythropolis bacteriophage YF1 inhibitory DNA 8 & & & & & $0.50 \%$ \\
\hline Otu0190 & Aeromonas phage DH1 clone SEQDH2 & & & & & $0.60 \%$ \\
\hline Otu0219 & Streptococcus phage 11865 & & & & & $0.70 \%$ \\
\hline Otu0223 & Bifidobacterium phage Bbif-1 & & & & & $0.80 \%$ \\
\hline Otu0229 & Sodalis phage SO-1 & & & & & $0.90 \%$ \\
\hline Otu0285 & Bacteriophage lambda insertion sequence IS5 & & & & & $1.00 \%$ \\
\hline Otu0288 & Cronobacter phage ES2 & & & & & \\
\hline Otu0298 & Gordonia phage GTE5 & & & & & \\
\hline Otu0301 & Mycobacterium phage DLane & & & & & \\
\hline Otu0311 & Mycobacterium phage Doom & & & & & \\
\hline Otu0326 & Mycobacterium phage Babsiella & & & & & \\
\hline Otu0328 & Mycobacterium phage Stinger & & & & & \\
\hline Otu0333 & Shigella phage EP23 & & & & & \\
\hline Otu0348 & Enterobacter phage Enc34 & & & & & \\
\hline Otu0349 & Unidentified phage clone 1013_scaffold24 & & & & & \\
\hline Otu0378 & Caulobacter phage CcrRogue & & & & & \\
\hline Otu0380 & Mycobacteriophage Taj & & & & & \\
\hline Otu0436 & Mycobacteriophage Daenerys & & & & & \\
\hline Otu0450 & Phage Salvo & & & & & \\
\hline Otu0518 & Enterobacteria phage RB68 & & & & & \\
\hline Otu0589 & Burkholderia phage BcepGomr & & & & & \\
\hline Otu0691 & Bacillus phage phIS3501 & & & & & \\
\hline Otu0801 & Erwinia phage Ea9-2 & & & & & \\
\hline Otu0802 & Acinetobacter phage Presley & & & & & \\
\hline
\end{tabular}

Figure 6. Sensitive viral phylotypes selected by expected effect size (EES) and differential expression analysis (DEA).

\subsection{Linkage between Operational Conditions and Viral Phylotypes}

The multivariate redundancy analysis linked the physicochemical data and dominant virus phylotypes with biological samples of the wastewater treatment procedure (Figure 7). Therefore, the results showed that biological samples from the effluent water were related to high physicochemical performance in terms of organic matter, nitrogen, and phosphorous removal. In the same way, Otu0521, Otu0326, and Otu0092 were affiliated taxonomically with Pseudomonas phage D3, Aeromonas phage vB_AsaM-56, and Pseudomonas Phage LKA1, respectively. These results combine the activity of bacteriophages with a higher removal ratio, suggesting a bacterial population control by the bacteriophages community.

The Otu0420 virus phylotype affiliated with E. coli phage 1720, was linked with the sludge, and was exclusively present in this kind of sample. In the same way, several viral OTUs were positively correlated with mixed liquor samples obtained from the aerobic reactor, such as Edwardsiella phage MSW-3, Pseudomonas phage H66, Burkolderia cepacia phage Bcep22, Bordetella phage BIP-1, and others. These results suggested that these phylotypes play an essential role in the control of the bacterial community structure and dynamics of the biological process in the WWTP 


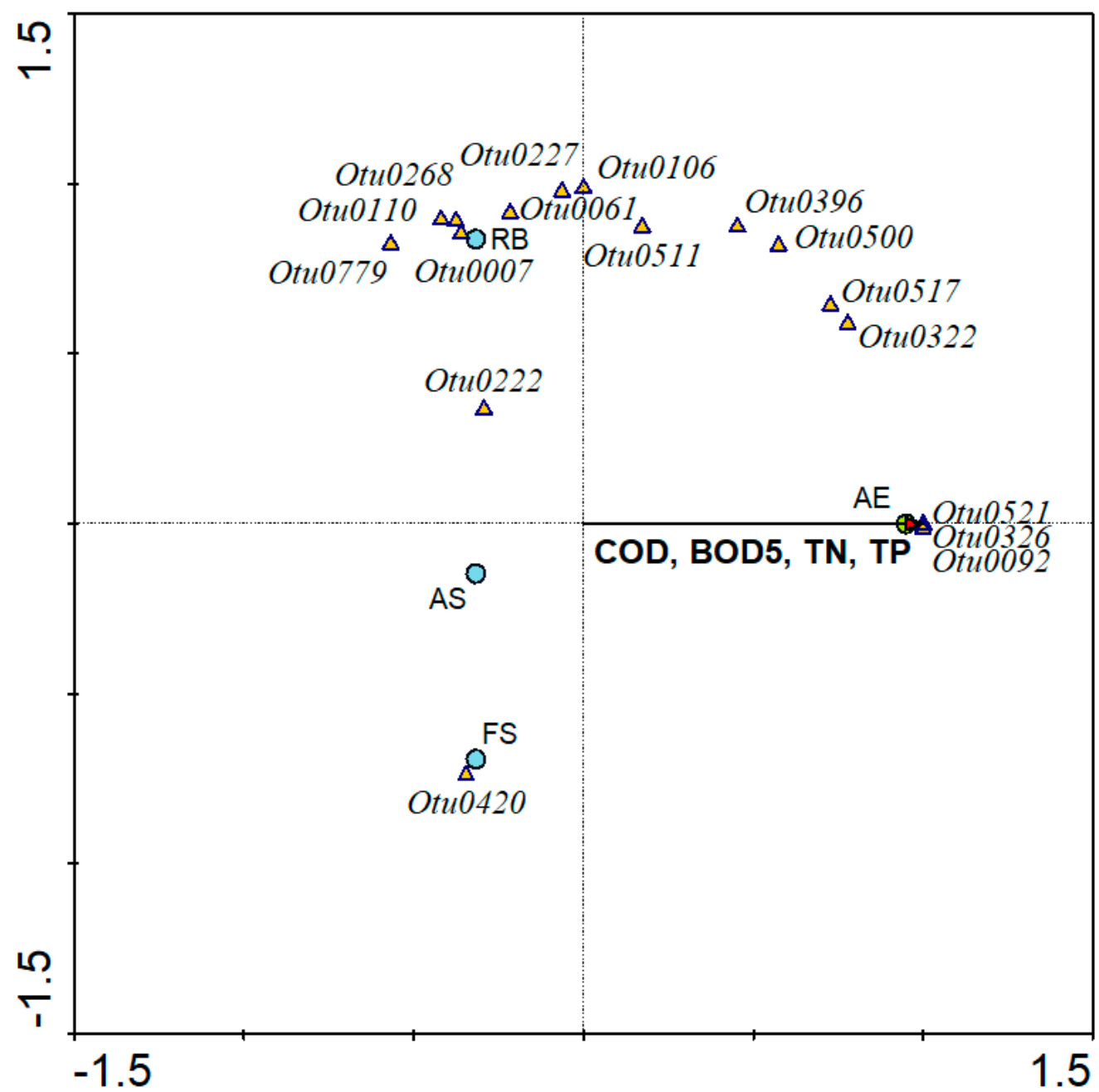

Figure 7. Multivariate redundancy analysis of dominant viral OTUs with physicochemical parameters and samples. IW: influent wastewater; EW: effluent water; ES: excess sludge; and ML: mixed liquor from an aerobic bioreactor. COD: chemical oxygen demand, $\mathrm{BOD}_{5}$ : biological oxygen demand, $\mathrm{TN}$ : total nitrogen; TP: total phosphorous. OTU affiliation is shown in Figure 2.

\section{Conclusions}

This study investigated the total virome in a full-scale conventional activated sludge treatment plant and its efficiency in virus removal. The results suggested a low potential risk to human health after biological treatment of the urban wastewater, due to the low relative abundance of human pathogenic viruses found in the effluent water and excess sludge. In conclusion, dominant viral communities detected were bacteriophages, and Escherichia coli $\mathrm{O} 157$ typing phage 7 was the dominant phylotype, which acquired a considerable potential role in the viral community composition of all collected samples. The transmission electron microscopy studies and the cluster analysis showed the different dynamics of viral samples before (influent wastewater) and after (effluent water, mixed liquor, and sludge) biological treatment affecting mainly to bacteriophages.

Author Contributions: C.G.-F.: methodology and formal analysis, A.R.-S.: software and formal analysis, B.M.-P.: writing-original draft preparation, A.G.-M.: writing—review and editing, M.V.-C.: writing-review, J.G.-L.: writing-review and editing, supervision, and funding acquisition. All authors have read and agreed to the published version of the manuscript.

Funding: This research was funded by Municipal Water Company of Granada (EMASAGRA S.A.). 
Acknowledgments: The authors would like to acknowledge the support given by the Institute of Water Research of University of Granada and the disposition of Municipal Water Company of Granada (EMASAGRA S.A.) for financial support to carry out the research.

Conflicts of Interest: The authors declare no conflict of interest.

\section{References}

1. Breitbart, M.; Rohwer, F. Here a virus, there a virus, everywhere the same virus? Trends Microbiol. 2005, 13, 278-284. [CrossRef] [PubMed]

2. Kaas, L.; Gourinat, A.C.; Urbès, F.; Langlet, J. A 1-year study on the detection of human enteric viruses in New Caledonia. Food Environ. Virol. 2016, 8, 46-56. [CrossRef] [PubMed]

3. Qiu, Y.; Li, Q.; Lee, B.E.; Ruecker, N.J.; Neumann, N.F.; Ashbolt, N.J.; Pang, X. UV inactivation of human infectious viruses at two full-scale wastewater treatment plants in Canada. Water Res. 2018, 147, 73-81. [CrossRef]

4. O'Brien, E.; Munir, M.; Marsh, T.; Heran, M.; Lesage, G.; Tarabara, V.V.; Xagoraraki, I. Diversity of DNA viruses in effluents of membrane bioreactors in Traverse City, MI (USA) and La Grande Motte (France). Water Res. 2017, 111, 338-345. [CrossRef] [PubMed]

5. Ashbolt, N.J. Microbial contamination of drinking water and human health from community water systems. Curr. Environ. Health Rep. 2015, 2, 95-106. [CrossRef] [PubMed]

6. World Health Organization. Novel Coronavirus (2019- $n$ CoV) Technical Guidance; World Health Organization: Geneva, Switzerland, 2020.

7. Bibby, K. Metagenomic identification of viral pathogens. Trends Biotechnol. 2013, 31, 275-279. [CrossRef] [PubMed]

8. Okoh, A.I.; Sibanda, T.; Gusha, S.S. Inadequately treated wastewater as a source of human enteric viruses in the environment. Int. J. Environ. Res. Public Health 2010, 7, 2620-2637. [CrossRef]

9. Wang, Y.; Jiang, X.; Liu, L.; Li, B.; Zhang, T. High-resolution temporal and spatial patterns of Virome in wastewater treatment systems. Environ. Sci. Technol. 2018, 52, 10337-10346. [CrossRef]

10. Nielsen, P.H.; Saunders, A.M.; Hansen, A.A.; Larsen, P.; Nielsen, J.L. Microbial communities involved in enhanced biological phosphorus removal from wastewater-A model system in environmental biotechnology. Curr. Opin. Biotechnol. 2012, 23, 452-459. [CrossRef]

11. Carducci, A.; Tozzi, E.; Rubulotta, E.; Casini, B.; Cantiani, L.; Rovini, E.; Muscillo, M.; Pacini, R. Assessing airborne biological hazard from urban wastewater treatment. Water Res. 2000, 34, 1173-1178. [CrossRef]

12. US EPA. Prepublication of the Ground Water Rule Federal Register Notice; US EPA: Washington, DC, USA, 2006.

13. Marion, J.W.; Lee, C.; Lee, C.S.; Wang, Q.; Lemeshow, S.; Buckley, T.J.; Saif, L.J.; Lee, J. Integrating bacterial and viral water quality assessment to predict swimming-associated illness at a freshwater beach: A cohort study. PLoS ONE 2014, 11, e112029. [CrossRef] [PubMed]

14. Gomila, M.; Solis, J.J.; David, Z.; Ramon, C.; Lalucat, J. Comparative reductions of bacterial indicators, bacteriophage-infecting enteric bacteria and enteroviruses in wastewater tertiary treatments by lagooning and UV-radiation. Water Sci. Technol. 2008, 58, 2223-2233. [CrossRef] [PubMed]

15. Simmons, F.J.; Xagoraraki, I. Release of infectious human enteric viruses by full-scale wastewater utilities. Water Res. 2011, 45, 3590-3598. [CrossRef]

16. Carducci, A.; Morici, P.; Pizzi, F.; Battistini, R.; Rovini, E.; Verani, M. Study of the viral removal efficiency in a urban wastewater treatment plant. Water Sci. Technol. 2008, 58, 893-897. [CrossRef] [PubMed]

17. Qadir, M.; Wichelns, D.; Raschid-Sally, L.; Minhas, P.S.; Drechsel, P.; Bahri, A.; Ensink, J.H. Agricultural use of marginal-quality water-Opportunities and challenges. In Water for Food, Water for Life. A Comprehensive Assessment of Water Management in Agriculture; IWMI \& Earthscan: London, UK; Ottawa, ON, Canada, 2017; No. 612-2016-40578.

18. Molle, B.; Brelle, F.; Bessy, J.; Gatel, D. Which water quality for which uses? Overcoming over-zealous use of the precautionary principle to reclaim wastewater for appropriate irrigation uses. Irrig. Drain. 2012, 61, 87-94. [CrossRef]

19. Drechsel, P.; Evans, A.E.V. Wastewater reuse in irrigated agriculture. Irrig. Drain. Syst. 2010, $24,1-152$. [CrossRef] 
20. Nuanualsuwan, S.; Thongtha, P.; Kamolsiripichaiporn, S.; Subharat, S. UV inactivation and model of UV inactivation of foot-and-mouth disease viruses in suspension. Int. J. Food Microbiol. 2008, 127, 84-90. [CrossRef] [PubMed]

21. Martínez-Puchol, S.; Rusiñol, M.; Fernández-Cassi, X.; Timoneda, N.; Itarte, M.; Andrés, C.; Anton, C.; Abril, J.F.; Girones, R.; Bofill-Mas, S. Characterisation of the sewage virome: Comparison of NGS tools and occurrence of significant pathogens. Sci. Total Environ. 2020, 713, 136604. [CrossRef]

22. Adriaenssens, E.M.; Farkas, K.; Harrison, C.; Jones, D.L.; Allison, H.E.; McCarthy, A.J. Viromic analysis of wastewater input to a river catchment reveals a diverse assemblage of RNA viruses. mSystems 2018, 3. [CrossRef]

23. Fernandez-Cassi, X.; Timoneda, N.; Martínez-Puchol, S.; Rusinol, M.; Rodriguez-Manzano, J.; Figuerola, N.; Bofill-Mas, S.; Abril, J.F.; Girones, R. Metagenomics for the study of viruses in urban sewage as a tool for public health surveillance. Sci. Total Environ. 2018, 618, 870-880. [CrossRef]

24. Maza-Márquez, P.; Castellano-Hinojosa, A.; González-Martínez, A.; Juárez-Jiménez, B.; González-López, J.; Rodelas, B. Abundance of total and metabolically active Candidatus Microthrix and fungal populations in three full-scale wastewater treatment plants. Chemosphere 2019, 232, 26-34. [CrossRef] [PubMed]

25. Aw, T.G.; Howe, A.; Rose, J.B. Metagenomic approaches for direct and cell culture evaluation of the virological quality of wastewater. J. Virol. Methods 2014, 210, 15-21. [CrossRef] [PubMed]

26. Reyes, A.; Semenkovich, N.P.; Whiteson, K.; Rohwer, F.; Gordon, J.I. Going viral: Next-generation sequencing applied to phage populations in the human gut. Nat. Rev. Microbiol. 2012, 10, 607-617. [CrossRef] [PubMed]

27. Marston, D.A.; McElhinney, L.M.; Ellis, R.J.; Horton, D.L.; Wise, E.L.; Leech, S.L.; David, D.; de Lamballerie, X.; Fooks, A.R. Nextion sequencing of viral RNA genomes. BMC Genom. 2013, 14, 444. [CrossRef] [PubMed]

28. Rosario, K.; Nilsson, C.; Lim, Y.W.; Ruan, Y.; Breitbart, M. Metagenomic analysis of viruses in reclaimed water. Environ. Microbiol. 2009, 11, 2806-2820. [CrossRef] [PubMed]

29. Hayat, M.A.; Miller, S.E. Negative Staining; McGraw-Hill: New York, NY, USA, 1990.

30. Schloss, P.D.; Westcott, S.L.; Ryabin, T.; Hall, J.R.; Hartmann, M.; Hollister, E.B.; Lesniewski, R.A.; Oakley, B.B.; Parks, D.H.; Robinson, C.J.; et al. Introducing mothur: Open-source, platform-independent, community-supported software for describing and comparing microbial communities. Appl. Environ. Microbiol. 2009, 75, 7537-7541. [CrossRef]

31. Altschul, S.F. BLAST algorithm. ELS 2001. [CrossRef]

32. Zhao, G.; Wu, G.; Lim, E.S.; Droit, L.; Krishnamurthy, S.; Barouch, D.H.; Virgin, H.W.; Wang, D. VirusSeeker, a computational pipeline for virus discovery and virome composition analysis. Virology 2017, 503, 21-30. [CrossRef]

33. Goodacre, N.; Aljanahi, A.; Nandakumar, S.; Mikailov, M.; Khan, A.S. A reference viral database (RVDB) to enhance bioinformatics analysis of high-throughput sequencing for novel virus detection. mSphere 2018, 3. [CrossRef]

34. Bian, G.; Gloor, G.B.; Gong, A.; Jia, C.; Zhang, W.; Hu, J.; Burton, J.P. The Gut Microbiota of Healthy Aged Chinese Is Similar to That of the Healthy Young. mSphere 2018, 2. [CrossRef]

35. Hartman, K.; van der Heijden, M.G.A.; Wittwer, R.A.; Banerjee, S.; Walser, J.-C.; Schlaeppi, K. Cropping practices manipulate abundance patterns of root and soil microbiome members paving the way to smart farming. Microbiome 2018, 6. [CrossRef]

36. Muñoz-Palazon, B.; Rodriguez-Sanchez, A.; Hurtado-Martinez, M.; Santana, F.; Gonzalez-Lopez, J.; Mack, L.; Gonzalez-Martinez, A. Polar Arctic Circle biomass enhances performance and stability of aerobic granular sludge systems operated under different temperatures. Bioresour. Technol. 2020, 300, 122650. [CrossRef] [PubMed]

37. Rosani, U.; Gerdol, M. A bioinformatics approach reveals seven nearly-complete RNA-virus genomes in bivalve RNA-seq data. Virus Res. 2017, 239, 33-42. [CrossRef] [PubMed]

38. Wu, B.; Wang, R.; Fane, A.G. The roles of bacteriophages in membrane-based water and wastewater treatment processes: A review. Water Res. 2017, 110, 120-132. [CrossRef]

39. Tanji, Y.; Mizoguchi, K.; Yoichi, M.; Morita, M.; Kijima, N.; Kator, H.; Unno, H. Seasonal change and fate of coliphages infected to Escherichia coli O157: H7 in a wastewater treatment plant. Water Res. 2003, 37, 1136-1142. [CrossRef]

40. Zhang, Y.; Hunt, H.K.; Hu, Z. Application of bacteriophages to selectively remove Pseudomonas aeruginosa in water and wastewater filtration systems. Water Res. 2013, 47, 4507-4518. [CrossRef] 
41. Kitajima, M.; Iker, B.C.; Pepper, I.L.; Gerba, C.P. Relative abundance and treatment reduction of viruses during wastewater treatment processes-Identification of potential viral indicators. Sci. Total Environ. 2014, 488, 290-296. [CrossRef]

42. Hata, A.; Kitajima, M.; Katayama, H. Occurrence and reduction of human viruses, F-specific RNA coliphage genogroups and microbial indicators at a full-scale wastewater treatment plant in Japan. J. Appl. Microbiol. 2013, 114, 545-554. [CrossRef]

43. Ateba, C.N.; Akindolire, M.A. Isolation and characterisation of bacteriophages with lytic activity against virulent Escherichia coli O157: H7: Potential bio-control agents. Preprints 2019, 2019010132. [CrossRef]

44. Hewitt, J.; Leonard, M.; Greening, G.E.; Lewis, G.D. Influence of wastewater treatment process and the population size on human virus profiles in wastewater. Water Res. 2011, 45, 6267-6276. [CrossRef]

45. Gulino, K.; Rahman, J.; Badri, M.; Morton, J.; Bonneau, R.; Ghedin, E. Initial Mapping of the New York City Wastewater Virome. mSystems 2020, 5. [CrossRef] [PubMed]

46. Goh, S.; Newman, C.; Knowles, M.; Bolton, F.J.; Hollyoak, V.; Richards, S.; Daley, P.; Counter, D.; Smith, H.R.; Keppie, N.E. Coli O157 phage type 21/28 outbreak in North Cumbria associated with pasteurized milk. Epidemiol. Infect. 2002, 129, 451-457. [CrossRef] [PubMed]

47. Gabisoniya, T.G.; Loladze, M.Z.; Nadiradze, M.M.; Chakhunashvili, N.K.; Alibegashvili, M.G.; Tamarashvili, N.G.; Pushkina, V.A. Effects of bacteriophages on biofilm formation by strains of Pseudomonas aeruginosa. Appl. Biochem. Microbiol. 2016, 52, 293-297. [CrossRef]

48. Zhang, Y.; Hu, Z. Combined treatment of Pseudomonas aeruginosa biofilms with bacteriophages and chlorine. Biotechnol. Bioeng. 2013, 110, 286-295. [CrossRef] [PubMed]

49. De Smet, J.; Hendrix, H.; Blasdel, B.G.; Danis-Wlodarczyk, K.; Lavigne, R. Pseudomonas predators: Understanding and exploiting phage-host interactions. Nat. Rev. Microbiol. 2017, 15, 517. [CrossRef]

50. Chan, B.K.; Sistrom, M.; Wertz, J.E.; Kortright, K.E.; Narayan, D.; Turner, P.E. Phage selection restores antibiotic sensitivity in MDR Pseudomonas aeruginosa. Sci. Rep. 2016, 6, 26717. [CrossRef]

51. Munir, M.; Marsh, T.; Xagoraraki, I. Metagenomic insights into microbial diversity and resistance to antibiotics in wastewater treatment plants. In Environmental Engineering —Doctor of Philosophy; Michigan State University: Lansing, MI, USA, 2014; p. 10.

52. Shapiro, O.H.; Kushmaro, A. Bacteriophage ecology in environmental biotechnology processes. Curr. Opin. Biotech. 2011, 22, 449-455. [CrossRef]

53. Calero-Cáceres, W.; Muniesa, M. Persistence of naturally occurring antibiotic resistance genes in the bacteria and bacteriophage fractions of wastewater. Water Res. 2016, 95, 11-18. [CrossRef]

54. Wong, M.V.; Hashsham, S.A.; Gulari, E.; Rouillard, J.M.; Aw, T.G.; Rose, J.B. Detection and characterization of human pathogenic viruses circulating in community wastewater using multi target microarrays and polymerase chain reaction. J. Water Health 2013, 11, 659-670. [CrossRef]

55. Alhamlan, F.S.; Ederer, M.M.; Brown, C.J.; Coats, E.R.; Crawford, R.L. Metagenomics-based analysis of viral communities in dairy lagoon wastewater. J. Microbiol. Meth. 2013, 92, 183-188. [CrossRef]

56. Foster, A.L.; Gaisa, M.M.; Hijdra, R.M.; Turner, S.S.; Morey, T.J.; Jacobson, K.B.; Fierer, D.S. Shedding of hepatitis $\mathrm{C}$ virus into the rectum of HIV-infected men who have sex with men. Clin. Infect. Dis. 2016, 64, 284-288. [CrossRef] [PubMed]

57. Withey, S.; Cartmell, E.; Avery, L.M.; Stephenson, T. Bacteriophages-Potential for application in wastewater treatment processes. Sci. Total Environ. 2005, 339, 1-18. [CrossRef] [PubMed]

58. Gerba, C.P.; Betancourt, W.Q.; Kitajima, M.; Rock, C.M. Reducing uncertainty in estimating virus reduction by advanced water treatment processes. Water Res. 2018, 133, 282-288. [CrossRef] [PubMed]

(C) 2020 by the authors. Licensee MDPI, Basel, Switzerland. This article is an open access article distributed under the terms and conditions of the Creative Commons Attribution (CC BY) license (http://creativecommons.org/licenses/by/4.0/). 